Research Article

\title{
Evaluation of Critical Parameters to Improve Slope Drainage System
}

\author{
Yong Weng Long, Siti Noor Linda Taib, and Onni Suhaiza Selaman
}

Faculty of Engineering, Universiti Malaysia Sarawak, Kota Samarahan, Malaysia

Correspondence should be addressed to Siti Noor Linda Taib; tlinda@unimas.my

Received 17 February 2017; Revised 30 June 2017; Accepted 17 August 2017; Published 21 December 2017

Academic Editor: Gianmarco de Felice

Copyright (C) 2017 Yong Weng Long et al. This is an open access article distributed under the Creative Commons Attribution License, which permits unrestricted use, distribution, and reproduction in any medium, provided the original work is properly cited.

\begin{abstract}
This study focuses on identifying and evaluating critical parameters of various drainage configurations, arrangement, and filter which affect the efficiency of water draining system in slopes. There are a total of seven experiments with different types of homogeneous soil, drainage envelope, filter material, and quantity of pipes performed utilizing a model box with a dimension of $0.8 \mathrm{~m} \times 0.8 \mathrm{~m} \times 0.6 \mathrm{~m}$. The pipes were orientated at 5 degrees from the horizontal. Rainfall event was introduced via a rainfall simulator with rainfall intensity of $434.1 \mathrm{~mm} / \mathrm{h}$. From the experiments performed, the expected outcomes when utilizing double pipes and geotextile as envelope filter were verified in this study. The results obtained from these experiments were reviewed and compared with Chapter 14 "Subsurface Drainage Systems" of DID's Irrigation and Agricultural Drainage Manual of Malaysia and the European standard. It is recommended that the pipe installed in the slope could be wrapped with geotextile and in tandem with application of granular filter to minimize clogging without affecting the water discharge rate. Terzaghi's filter criteria could be followed closely when deciding on new materials to act as aggregate filter. A caging system could be introduced as it could maintain the integrity of the drainage system and could ease installation.
\end{abstract}

\section{Introduction}

Malaysia is located in the tropics where heavy rainfall and thorough in situ chemical and mechanical weathering result in the development of deep residual soil profiles. Slope failures are affected rapidly by rising groundwater level and rainfall infiltration due to the frequent high-intensity tropical rainfalls. Installation of horizontal drains in slope is one of the common methods used by engineers to lower the amount of excess water in slopes. Horizontal drains could be defined as holes drilled into a slope and cased with perforated metal or slotted plastic linearly to drain out groundwater $[1,2]$. Horizontal drains have been used successfully to improve slope stability [2-7]. However, Martin et al. [8] stated that the prescriptive drainage systems are not critical in achieving a specified factor of safety.

According to Ahmed et al. [2], the earliest usage of horizontal drains was recorded in 1843 in Great Britain to stabilize railway slopes which involved very deep cuts, while in the USA, its usage was first reported in 1939, but the method only gained acceptance within the continent in the early 1970s. Stanton [9] reported the successful use of horizontal drains to numerous landslides by the California Division of Highways. In Australia, its usage was first reported in the mid-1960s, while in France it was first used in 1954. Craig and Gray [10] found that, in Hong Kong, horizontal drains have been used at shallow depths, rarely more than $20 \mathrm{~m}$ in length since 1973 .

However, it is observed that a number of slope drainage systems utilizing horizontal drains in Malaysia did not function properly in the long term and drained the water inefficiently from slopes. Clogging of drainage pipes by soil sediments which leads to reduced efficiency in draining water is a typical condition that inevitably could cause slope failures. Hence, there is a need to understand the influence of these technical parameters to help improve the existing prescriptive design. In Malaysia, manuals available for designing the pipe drains are Urban Stormwater Management Manual for Malaysia (MSMA) and Irrigation 


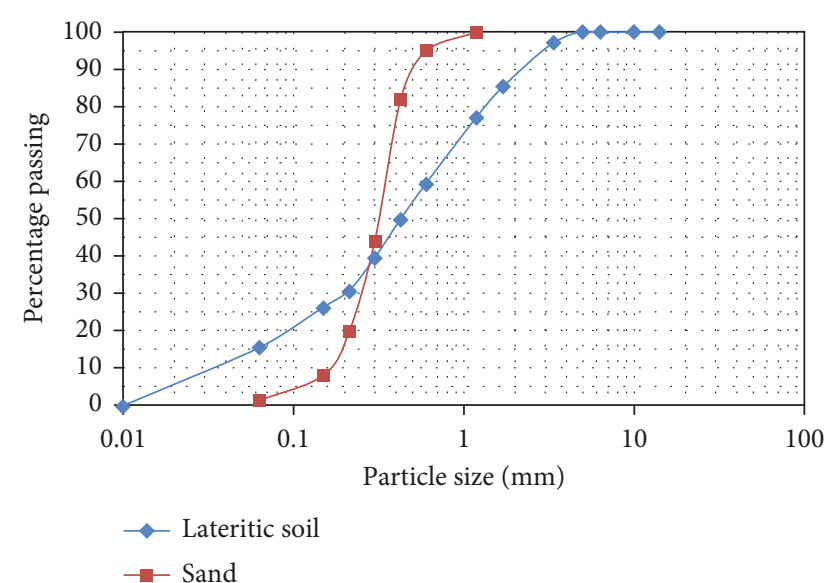

FIgUre 1: Particle size distribution of sand and lateritic soil in this study.

and Agricultural Drainage Manual from the Government of Malaysia's Department of Irrigation and Drainage (DID).

This paper focuses on evaluating various critical parameters in the design of slope drainage system. The identified parameters, namely, the drainage pipe configuration, filter design, soil types, and pipe arrangement, were tested for their influence towards the drainage system's efficiency. All experiments were performed in the Geotechnical Engineering Laboratory, Universiti Malaysia Sarawak (UNIMAS). Several conditions were maintained throughout the experiments: the soils (1) were kept homogeneous and (2) were of type cohesive and noncohesive. Rainfall simulator was used to simulate typical heavy rainfall condition in Malaysia.

\section{Materials and Methods}

The soils used in this study were sand and lateritic soil. A number of filter materials were utilized, namely, quarry gravels and oil palm shells, as aggregate-type filters, while geotextile and nylon square net fabric were used as envelopetype filters. The pipe chosen was perforated high-density polyethylene (HDPE) pipe. All tests were performed in a model box equipped with a rainfall simulator.

Sand was sieved with $1.18 \mathrm{~mm}$ sieve, and the particle size distribution for the sand is as presented in Figure 1. The coefficient of uniformity, $C_{u}$, was 2.035 , which indicates that the soil is uniformly graded. For the lateritic soil, $C_{u}$ was 19.06 , and the coefficient of curvature $\left(C_{c}\right)$ was 2.26 . Figure 1 presents the particle size distribution of the soil. According to Ishibashi and Hazarika [11], the lateritic soil was classified as silty soil with high plasticity by referring to the USCS chart. It was well graded as it satisfied the $C_{u} \geq 6$ and $1 \leq C_{c} \leq 3$ requirement. Based on Atterberg's limit test, the plasticity index and liquid limit of the lateritic soil were $45 \%$ and $95 \%$, respectively. The targeted moisture content for the sand and lateritic soils to overcome the water repellence problem was $18.6 \%$ and $22 \%$, respectively. Hence, the unit weights of the wet

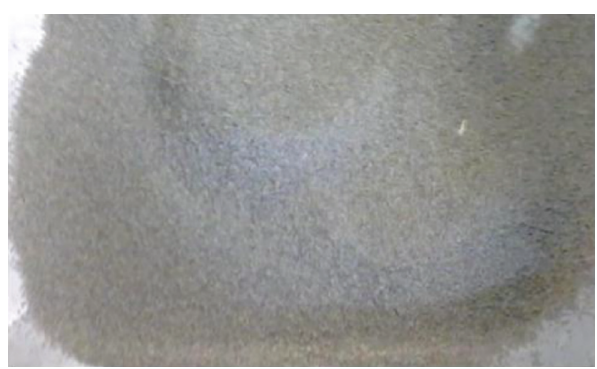

(a)

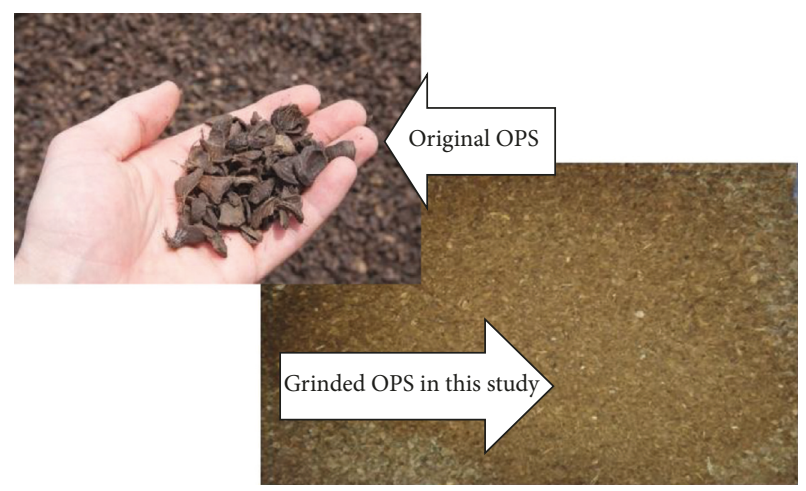

(b)

FIGURE 2: Filter materials. (a) Quarry gravels and (b) oil palm shells (OPSs).

sand and lateritic soils were $14 \mathrm{kN} / \mathrm{m}^{3}$ and $12 \mathrm{kN} / \mathrm{m}^{3}$, respectively.

The proposed filter materials were quarry gravels with size in the range of $1.18 \mathrm{~mm}$ to $1.70 \mathrm{~mm}$ and oil palm shells with size in the range of $1.70 \mathrm{~mm}-3.35 \mathrm{~mm}$. According to Terzaghi's filter criteria [12], the particle diameter of $15 \%$ size of the filter material $\left(d_{15}\right)$ should be greater than 4 times the diameter of $15 \%$ size of the soil material $\left(D_{15}\right)$ and smaller than 4 times the diameter of $85 \%$ size of the soil material $\left(D_{85}\right)$. Therefore, the required particle size for a filter material is between $0.77 \mathrm{~mm}$ and $1.88 \mathrm{~mm}$ to comply with the criteria. The gravel filter satisfied the criteria, whereas the oil palm shells did not due to limitation of crusher machine. However, a prospect of using waste materials as filter is seen interesting to be investigated and was maintained. Figure 2 shows the filter materials utilized in this study.

The HDPE pipe in the experiment was designed and scaled based on the Simona design [13]. The Simona design incorporates partial perforation. However, some modifications from the design were performed as to suit to the experiment requirement. The HDPE pipe was chosen as it has excellent resistance to corrosion, long service life, chemical resistance, and high abrasion resistance which make it ideal for water supply and drainage. The shape of perforation was circle with a diameter of $4 \mathrm{~mm}$, and the distance between center and center of the holes was $70 \mathrm{~mm}$ as shown in Figure 3(a). The perforations in the pipe were located in the upper section of the pipe (partial drainage pipe) and were symmetrical to the pipe's vertical axis at an angle of 220 degrees (Figure 3(b)). The partial drainage pipe was proposed because of the nature of the study in which the 


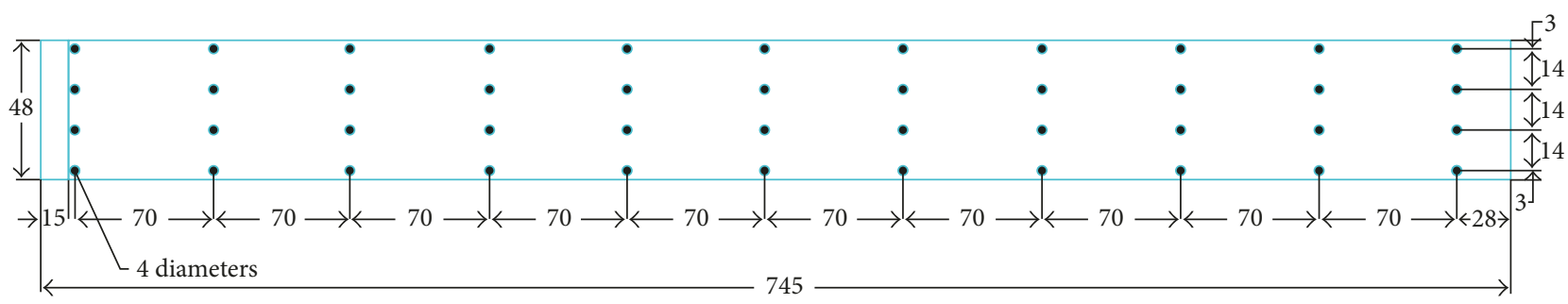

(a)

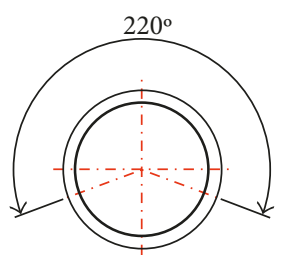

(b)

FIgure 3: Details of perforations in the HDPE pipe. (a) Placement of perforations on the HDPE pipe and (b) partial pipe drainage.

TABle 1: Proposed partial drainage pipes' configuration.

\begin{tabular}{lccc}
\hline Parameters & Experiments in this study & Simona (2012) & Scale (experiment : real) \\
\hline Nominal diameter, $\mathrm{DN}(\mathrm{mm})$ & 25 & 250 & $1: 10$ \\
Outside diameter, $d(\mathrm{~mm})$ & 25 & 250 & $1: 10$ \\
Thickness of pipe's wall $(\mathrm{mm})$ & 2.3 & 22.7 & $1: 9.87$ \\
Pipe's inside diameter, $d_{i}(\mathrm{~mm})$ & 20.4 & 204.76 & $1: 10$ \\
Size of holes, $\mathrm{Li}(\mathrm{mm})$ & 4 (diameter of circle) & 30 (rectangular) & - \\
Number of slots, $n$ & 4 & 3 & - \\
\hline
\end{tabular}

TABLE 2: Scale factor between pipes in this study and Nanyang.

\begin{tabular}{lccc}
\hline Parameters & Experiments & Nanyang & Scale (experiment : Nanyang) \\
\hline Length $(\mathrm{m})$ & 0.72 & 6 & $1: 8.33$ \\
Diameter of pipe $(\mathrm{mm})$ & 25 & 89 & $1: 3.56$ \\
Horizontal spacing between pipe $(\mathrm{m})$ & 0.6 & 2 & $1: 3.33$ \\
Vertical spacing between pipe $(\mathrm{m})$ & 0.45 & 2 & $1: 4.44$ \\
Angle $\left(^{\circ}\right)$ & 5 & 5.7 & - \\
\hline
\end{tabular}

pipe was used to absorb strata and surface water through the perforation at the top and convey it to the next receiving water course in the enclosed bottom of the pipe. Table 1 shows the details of the proposed partial drainage pipes used in this study.

Geotextiles with an opening size of $0.12 \mathrm{~mm}$ were used as filter and pipe envelopes to prevent the movement of fine particles into the pipe. In addition, another material with larger opening $(1 \mathrm{~mm})$, nylon square net fabric, was also proposed.

A medium-sized experiment model box was used for the modeling, and it was scaled based on the pipes installed in a slope at Nanyang Heights in Singapore [14], which in detail is presented in Table 2. Nanyang's pipe arrangement was followed considering its similar tropical setting as in the case study. The dimensions of the model box are $0.8 \mathrm{~m}$ long, $0.6 \mathrm{~m}$ wide, and $0.6 \mathrm{~m}$ high (Figure 4 ). A steel frame is used to support the whole box structure. The bracing steel is to support the sides of the model box. The model box is designed to be leak proof.

A rainfall simulator shown in Figure 5 was to provide similar characteristics to the natural rainfall. A submersible pump (60 liter/minute (LPM) capacity) placed in a water tank was used to pump water to feed the rainfall simulator. Simulated rainfall was introduced through a water sprinkler system at a constant rate of water flow regulated by a flow meter installed in the system. Measurement of rainfall intensity was taken by using the spatial distribution method [15]. A rectangular test plot of $0.48 \mathrm{~m}^{2}$ (the size of actual plot) was located under the rainfall simulator and was introduced to rainfall for 5 minutes. Various falling heights (between nozzle and bottom of measuring cups) and flow rates were introduced before a final height of $57 \mathrm{~cm}$, flow rate of $18 \mathrm{LPM}$, and appropriate rainfall dispersion angle of $45^{\circ} 29^{\prime} 33^{\prime \prime}$ to cover the whole plot were reached. The simulated rainfall's intensity was attained by measuring the 


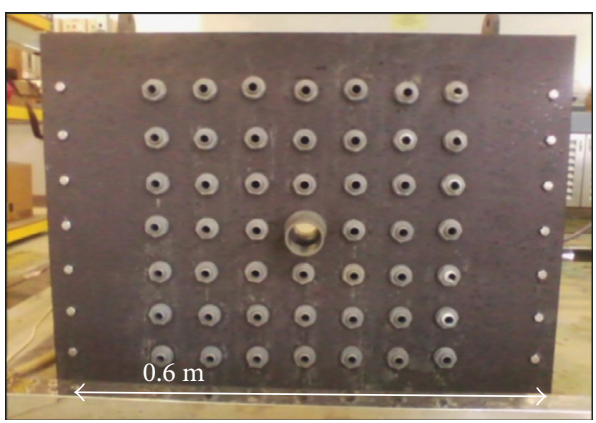

(a)

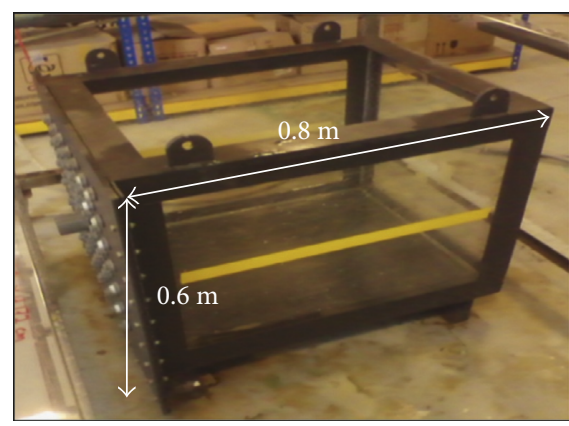

(b)

Figure 4: Model box. (a) Front view and (b) isometric view.

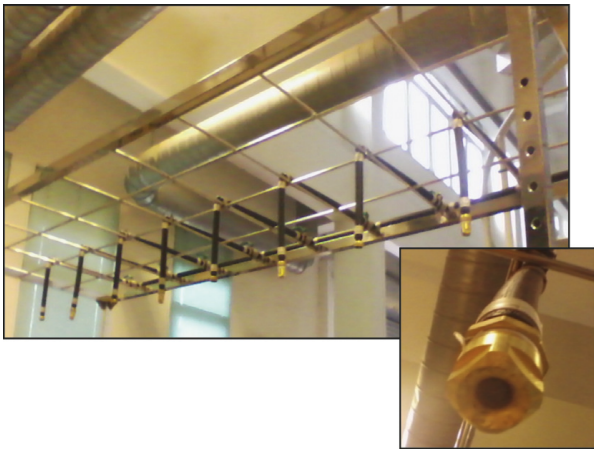

(a)

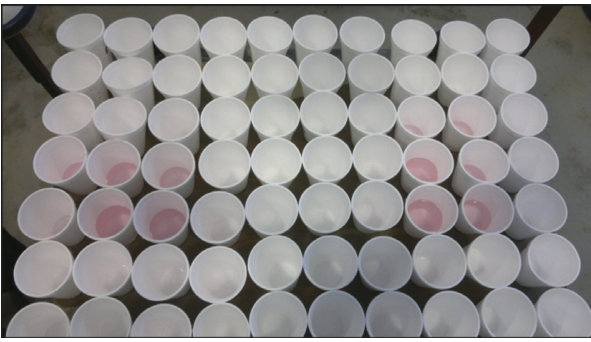

(b)

Figure 5: (a) Rainfall simulator and nozzle. (b) Measuring cups on $0.48 \mathrm{~m}^{2}$ test plot.

TABLe 3: Materials used for single- and double-pipe experiments.

\begin{tabular}{lcccccc}
\hline \multirow{2}{*}{ Amount of pipes } & \multicolumn{2}{c}{ Mass of soil (kg) } & \multicolumn{2}{c}{ Mass of water $(\mathrm{kg})$} & \multicolumn{2}{c}{ Mass of filter material (kg) } \\
& Sand & Lateritic soil & Sand & Lateritic soil & Oil palm shell & Quarry gravel \\
\hline Single & 167.28 & 139.41 & 31.11 & 30.67 & 1.674 & 4.9192 \\
Double & 161.76 & - & 30.09 & - & 3.348 & 9.8384 \\
\hline
\end{tabular}

height of water collected from the individual measuring cup as shown in Figure 5(b). Average rainfall intensity obtained for this study was $434.1 \mathrm{~mm} / \mathrm{h}$.

Table 3 presents the mass of materials used in all seven experiments performed in this study. The mass of sand and water for mixing purposes in experiment with single pipe was $167.28 \mathrm{~kg}$ and $31.11 \mathrm{~kg}$, respectively. The mass of sand and water in experiment with double pipes was $161.76 \mathrm{~kg}$ and $30.09 \mathrm{~kg}$, respectively, and the mass of lateritic soil and water in experiment with single pipe was $139.41 \mathrm{~kg}$ and $30.67 \mathrm{~kg}$, respectively. The varied masses were due to initial water content of the soil, and all materials were mixed with an aim to achieve the targeted wet density as mentioned in the earlier section.

Prior to securing the perforated HDPE pipe in the model box, a square caging of $80 \times 80 \mathrm{~mm}$ was prepared to house the pipe. Aggregate filter was filled into the caging and was wrapped with a layer of geotextile. The perforated HDPE pipe was also wrapped with a $6 \mathrm{~mm}$ thick geotextile filter envelope, and the wrapped pipe was later placed in the caging which was already partially filled with aggregate filter. The ready HDPE pipe enclosed in a caging filled with geotextile-wrapped aggregate filter is shown in Figure 6(a). The pipe in its caging was then attached to the bottom outlet of the model box shown in Figure 6(b), and the soil mixture was then placed at a height of $300 \mathrm{~mm}$. To attain the desired density, it was identified from a separate compaction test that applying firm hand pressure of about 25-30 presses for every soil lift of $50 \mathrm{~mm}$ thickness was sufficient. Also, to provide the 5-degree inclination of the pipe, an inclinable board resting on the bottom of the box was placed at the rear of the pipe. Once the soil model was ready, the rainfall simulator was then placed at the top of the model box as shown in Figure 6(c). Figure 7 shows the schematic diagram of the experiment's configuration. 


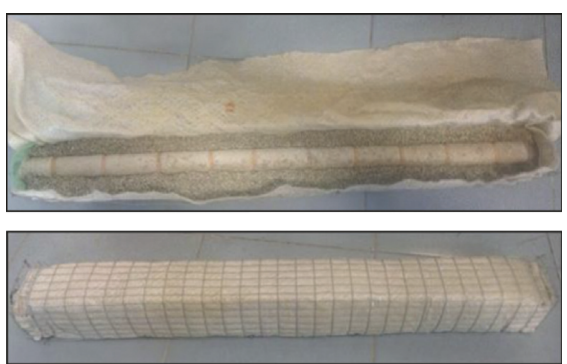

(a)

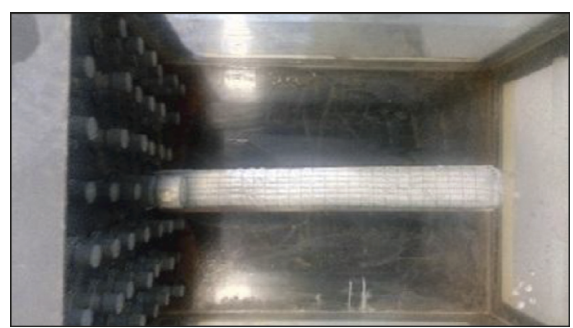

(b)

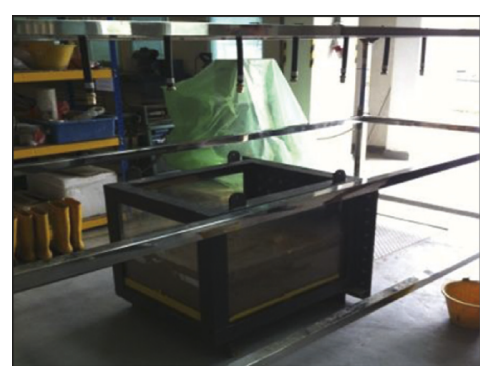

(c)

Figure 6: (a) Pipe in caging. (b) Setup of pipe in the model box. (c) Experimental setup (not to scale).

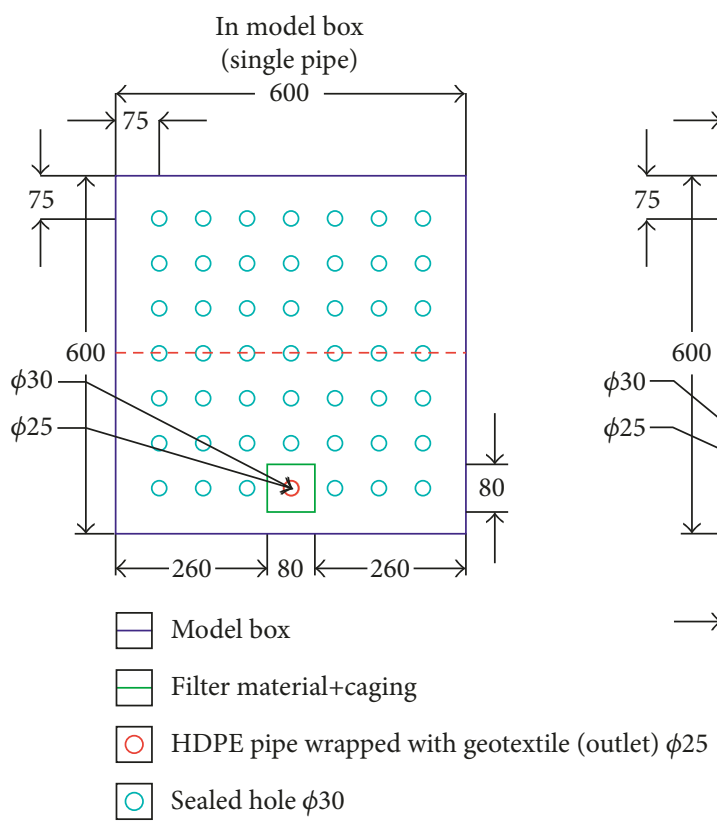

(a) (b)

FiguRE 7: Experiment's pipe arrangement in the model box (front view). (a) Single pipe and (b) multiple pipes (scale $1 \mathrm{~mm}: 21.4 \mathrm{~mm}$ ).

TABLE 4: Details of experiments performed in this study.

\begin{tabular}{ccccccccc}
\hline Test & $\begin{array}{c}\text { Types of } \\
\text { soil }\end{array}$ & $\begin{array}{c}\text { Saturated unit weight of } \\
\text { soil }\left(\mathrm{kN} / \mathrm{m}^{3}\right)\end{array}$ & $\begin{array}{c}\text { Quantity of pipe } \\
\text { installed }\end{array}$ & $\begin{array}{c}\text { Aggregate filter } \\
\text { material }\end{array}$ & $\begin{array}{c}\text { Envelope filter } \\
\text { material }\end{array}$ & $\begin{array}{c}\text { Pipe envelope } \\
(6 \mathrm{~mm} \text { thick })\end{array}$ & $\begin{array}{c}\text { Pipe } \\
\text { angle }\left({ }^{\circ}\right)\end{array}$ & $\begin{array}{c}\text { Rainfall } \\
\text { intensity } \\
(\mathrm{mm} / \mathrm{hr})\end{array}$ \\
\hline 1 & Sand & 14 & 1 & Quarry gravel & Geotextile & Geotextile & 5 & 434.1 \\
2 & Sand & 14 & 1 & Oil palm shell & Geotextile & Geotextile & 5 & 434.1 \\
3 & Sand & 14 & 2 & Quarry gravel & Geotextile & Geotextile & 5 & 434.1 \\
4 & Sand & 14 & 1 & Quarry gravel & Net & Geotextile & 5 & 434.1 \\
5 & Sand & 14 & 2 & Oil palm shell & Geotextile & Geotextile & 5 & 434.1 \\
6 & $\begin{array}{c}\text { Lateritic } \\
\text { soil }\end{array}$ & 12 & 1 & Quarry gravel & Geotextile & Geotextile & 5 & 434.1 \\
\hline
\end{tabular}

During the experiment, the mass of water discharged from the pipe was recorded every 1 minute for the duration of 7 minutes. After this, the remaining mass of water discharged was recorded in total amount at the end of discharge. Sediments in the collected water were weighed for their dry mass, and permeability of the soil was measured 
TABLE 5: Summary of results.

$(\mathrm{cm} / \mathrm{s})$

\begin{tabular}{|c|c|c|c|c|c|c|}
\hline & & & & & Before & After \\
\hline 1 & Sand & 1.26 & 7.07 & 0.00 & 0.06057 & 0.06006 \\
\hline 2 & Sand & 1.03 & 4.64 & 0.04 & 0.11124 & 0.08089 \\
\hline 3 & Sand & 1.35 & 10.48 & 2.07 & 0.11920 & 0.05412 \\
\hline 4 & Sand & 1.76 & 7.55 & 0.71 & 0.11324 & 0.07713 \\
\hline 5 & Sand & 1.31 & 9.03 & 5.24 & 0.13976 & 0.11571 \\
\hline 6 & Lateritic soil & 2.14 & 9.95 & 0.00 & 0.00201 & 0.00057 \\
\hline
\end{tabular}

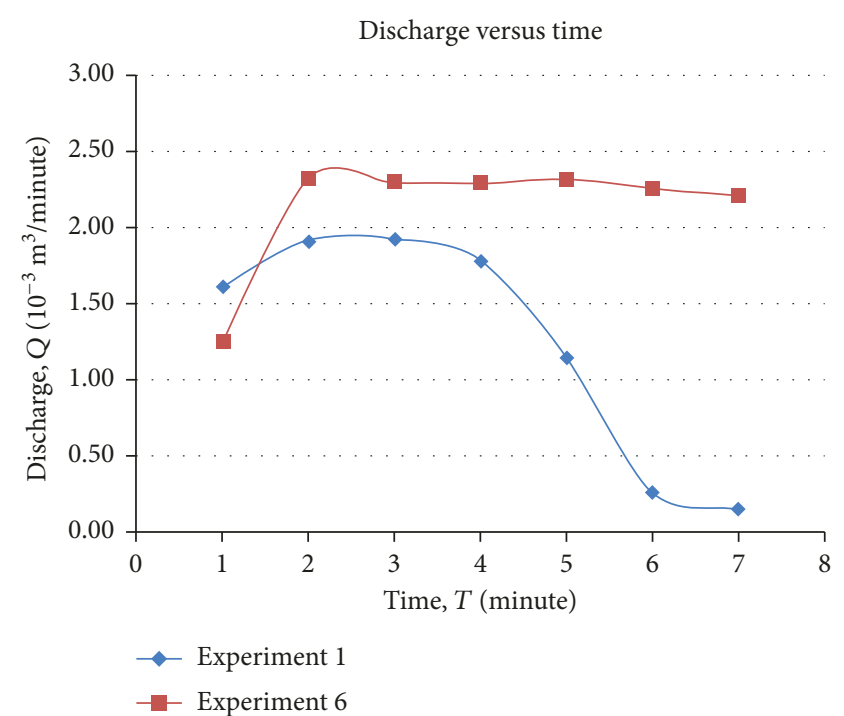

FIgURE 8: Comparison of discharge between Experiments 1 and 6 for the first 7 minutes.

before and after each test via a laboratory infiltrometer. The discharge rate of water and sediment in the water collected is the valuable information to distinguish the efficiency of the drainage in different variables. Discharge rate was calculated based on the first 7 minutes of water discharged. Percentage of water discharged was measured with respect to amount of rainwater introduced.

Table 4 shows the different scenarios introduced in the 6 experiments performed in this study. The differences between these 6 experiments are the types of soil, envelope filter material, aggregate filter material, quantity of perforated pipes installed, and types of pipe envelope.

\section{Results and Discussion}

Experimental results are discussed based on comparable scenarios between experiments, and Table 5 shows the summary of important findings which are the average discharge $\left(\mathrm{Q} ; \mathrm{m}^{3} / \mathrm{s}\right)$, percentage of water discharged, amount of sediments collected $(g)$, and permeability of soil before/after experiments $(\mathrm{cm} / \mathrm{s})$.

Experiments 1 and 6 are compared based on soil type. Both soils were mixed with their respective amount of water to achieve the targeted density. There was no sediment collected

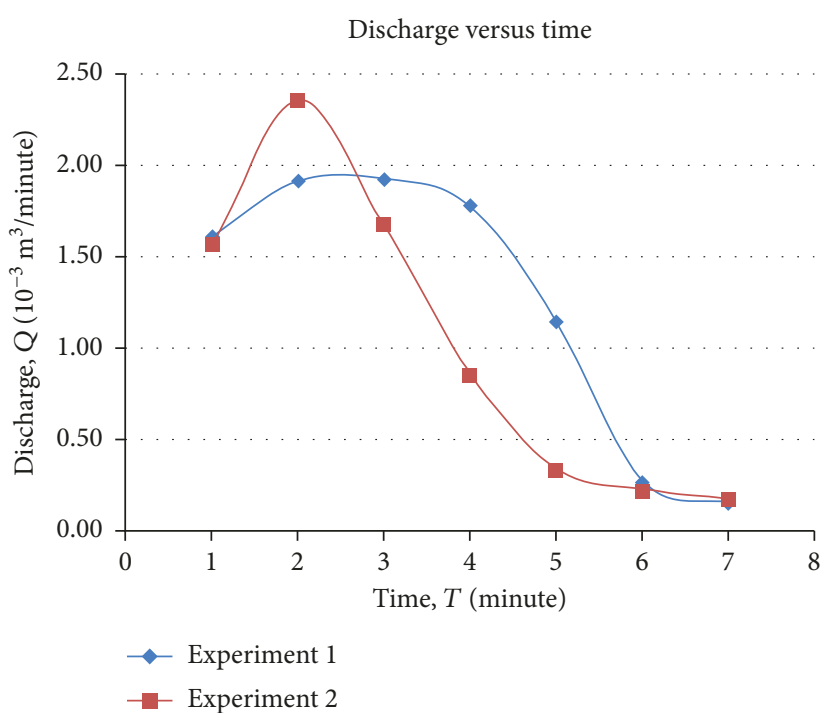

FIgure 9: Comparison of discharge between Experiments 1 and 2 for the first 7 minutes.

in the discharged water from both experiments. Peak discharge rates for Experiments 1 and 6 are $1.93 \times 10^{-3} \mathrm{~m}^{3} / \mathrm{min}$ and $2.32 \times 10^{-3} \mathrm{~m}^{3} / \mathrm{min}$, respectively. Both peak rates were recorded at about 120-150 seconds. Experiment 1 (sand) shows higher discharge rate compared with the lateritic soil model in Experiment 6 in the first 1.5 minutes. However, despite low permeability of the lateritic soil model, it can be observed after 1.5 minutes the discharge rate of the lateritic soil model is higher than in the sand model. In addition to that lateritic soils were able to drain more infiltrated water after sometime compared to sand. It was identified that this interesting condition appeared due to existence of retained or trapped water above the drainage pipe in the lateritic soil and on the surface of the soil. Its low permeability contributed to this interesting condition, and this can be observed in Figure 8 .

Experiments 1 and 4 are compared with respect to the drainage envelope. There was sediment collected in the discharged water from drainage system enveloped with net (Experiment 4). It can be observed from Table 5 that the discharge rate of Experiment 4 is higher than in Experiment 1 (with geotextile). The effective opening size of geotextile and net is $0.12 \mathrm{~mm}$ and $1 \mathrm{~mm}$, respectively. From the sieve analysis of sand, the effective opening size of the net allows the biggest sand particle and water to easily pass through and 


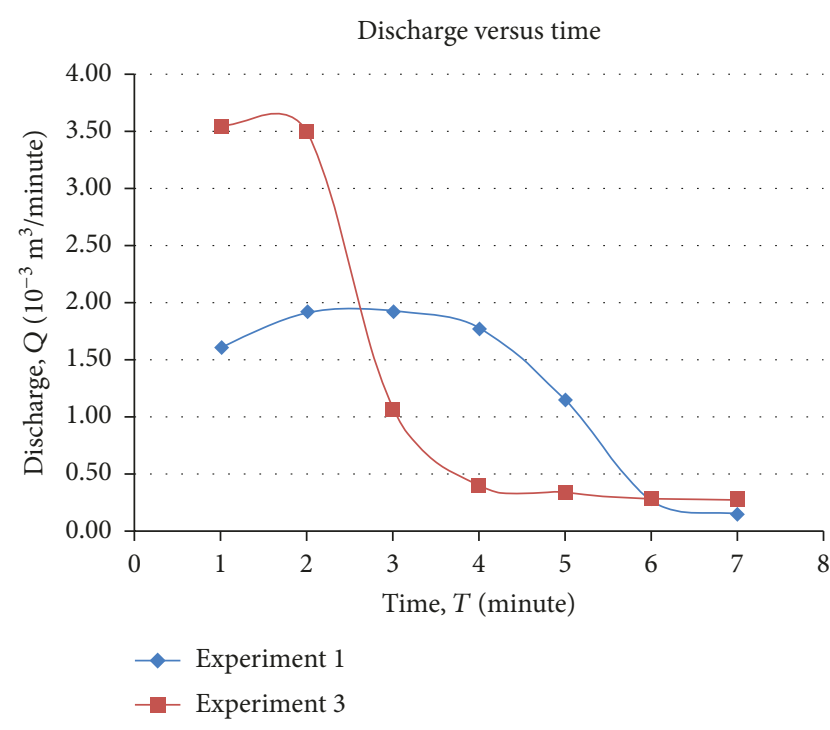

(a)

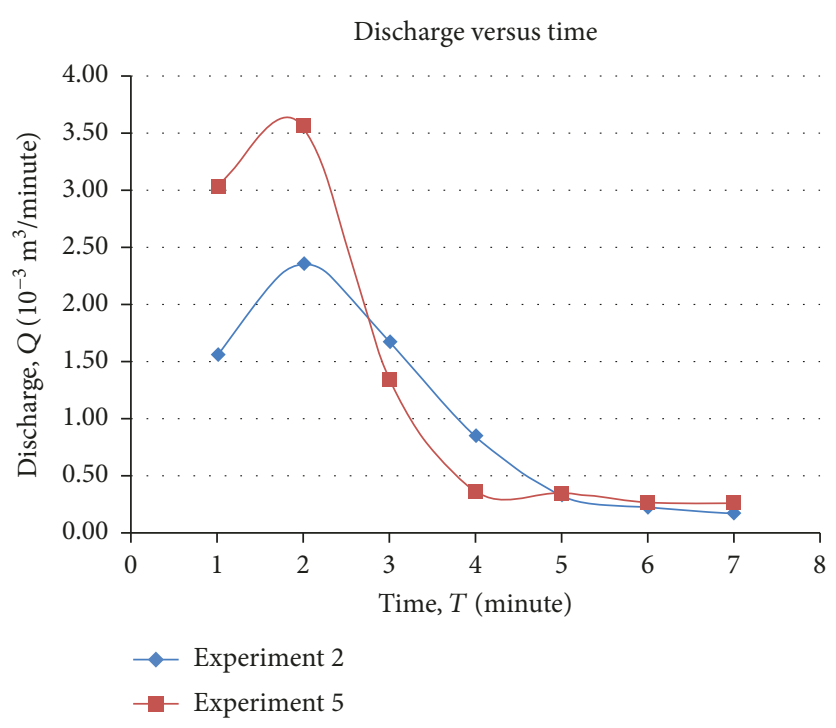

(b)

Figure 10: Comparison of discharge between (a) Experiments 1 and 3 and (b) Experiments 2 and 5 for the first 7 minutes.

thus resulted in the sediment collected at the end of the experiment. The requirement of a filter is to keep soil particles from invading the filter significantly. Hence, the proposed net is not appropriate to be used as a filter envelope in a drainage design.

Experiments 1 and 2 are compared in terms of aggregate filter material. There was sediment collected in the discharged water from Experiment 2 (oil palm shell). Peak discharge rates for Experiments 1 and 2 are $1.93 \times 10^{-3} \mathrm{~m}^{3} / \mathrm{min}$ and $2.36 \times 10^{-3} \mathrm{~m}^{3} / \mathrm{min}$, respectively. Both peak rates were recorded at about 120 seconds. However, it can be observed that the average discharge rate of Experiment 1 (quarry gravel) is higher than that of Experiment 2. From the particle size analysis on both soils, the particle size at $15 \%$ of oil palm shells is higher than that of the quarry gravels. Hence, the permeability rate of the oil palm shells is expected to be higher than that of the quarry gravels as the particle size of the oil palm shells is larger than that of the quarry gravels. Consequently, the porosity of the oil palm shells is also higher than that of the quarry gravels. Hence, the sediments recorded in Experiment 2 may be due to some of the soil particles which could have passed through the oil palm shells and flowed through the perforated pipe. In addition to that the particles in the quarry gravels and oil palm shells were not of the same size and shape as the colloidal theories assumed. Oil palm shells consist of fibres which allow clogging to occur at the outer surface of the perforated pipe; thus, sand was retained at the fibre of oil palm shell which led to much lower rate of water discharged. Figure 9 shows the rate of water discharge.

Experiments 1 and 3 (2 pipes) are compared in terms of quantity of pipes installed in the model box. The sediment collected in the discharged water from experiment with double perforated pipes was found to be higher than in the experiment with single pipe. Based on Table 5 , the discharge rate of experiment with double perforated pipes was higher than in the experiment with single perforated pipe. This is logical since the number of pipes was increased, the discharge rate of water was also increased. Similar findings were also shown in Experiment 5 in which higher discharge and sediment were found in double perforated pipes with oil palm shells as aggregate filter. Peak discharge rates for Experiments 1 and 3 are $1.93 \times 10^{-3} \mathrm{~m}^{3} / \mathrm{min}$ and $3.55 \times 10^{-3} \mathrm{~m}^{3} / \mathrm{min}$, respectively. Both peak rates were recorded at about $60-120$ seconds. Meanwhile, peak discharge rates for Experiments 2 and 4 are $2.36 \times 10^{-3} \mathrm{~m}^{3} / \mathrm{min}$ and $3.56 \times 10^{-3} \mathrm{~m}^{3} / \mathrm{min}$, respectively. Both peak rates were also recorded at about 120 seconds. Figure 10 shows the comparison.

From the comparisons made above, it is recommended that the pipe installed in the slope could be wrapped with geotextile and in tandem with application of granular filter to minimize clogging without affecting the discharge rate of water. This is evident from the findings in Experiments 1 (geotextile) and 4 (net) in which lower amount of sediments and good amount of water discharged were recorded in Experiment 1 which had combination of geotextile and gravel filter in a system.

Terzaghi's filter criteria could be followed closely when deciding on new materials to act as aggregate filter and findings in Experiments 1 (gravel filter) and 2 (OPS filter) support this statement. Some sediments were collected in Experiment 2 as OPSs had sizes not within the recommended range. Also, the fibrous nature of the material led to lower amount of discharge rate.

A caging system could be introduced as it could maintain the integrity of the drainage system and could ease installation. The 5-degree inclination of pipe is highly recommended because it provides higher hydraulic head and lower piezometric surface elevations at the back of the drains. Table 6 shows the comparison and recommendations made based on identified parameters and their influences. Comparison was made between the Malaysian DID manual, the European standard, and this study. 
TABLE 6: Recommendation between study, European standard, and DID manual.

\begin{tabular}{lccc}
\hline Parameters & Study & European standard (2005) & DID manual (2009) \\
\hline Angle of drain installed & $5^{\circ}$ & None & $0.06^{\circ}$ \\
Pipe envelope & Geotextile & $\begin{array}{c}\text { Geotextile with at least } 5 \text { mm thickness. Comply with } \\
\text { ISO 9863, 9864, and 12956 in terms of mass per unit } \\
\text { area, pore size index, and wettability }\end{array}$ & None \\
Drainage envelope & Geotextile and granularfilter material & None & Granularfiltermaterial \\
\hline
\end{tabular}

\section{Conclusions and Recommendations}

The aim of this study was to identify the parameters which are important in designing slope drainage system and to recommend a design suggestion incorporating identified parameters and their influences. The following conclusions can be drawn from the study:

(i) Based on the literature review and 6 experiments performed, the parameters which are important in designing slope drainage system are angle of pipes installed, spacing between pipes, size and arrangement of pipes, pipe perforation, and filter materials.

(ii) The proposed filter materials which are oil palm shells and net did not perform well in terms of sediment collected as they do not comply with the relationship between particle size and effective opening size. This criterion must be observed closely when deciding new filter materials.

(iii) In terms of sediment collected in discharged water, the pipe was enveloped with geotextile, and quarry gravels in both soils were able to reduce clogging in the pipe.

(iv) In terms of discharge rate and percentage of water discharged, the void ratio of the soils and granular filter material played an important role because the higher the void ratio, the higher the permeability and the discharge rate. However, in cases where permeability is low, amount of water discharged may be significant after sometime as found in this study.

(v) By comparing with the Malaysian DID manual, it is recommended that the pipe to be installed in the slope is to be wrapped with geotextile to minimize clogging. The inclination of the pipe from the horizontal is recommended because it provides higher hydraulic head and lower piezometric surface elevations at the back of the drains. A study is recommended on finding a suitable range of angles.

(vi) Long-term performance of the drainage system could be further investigated. Critical factors that can be identified from this study are (1) structural integrity of the drainage system which could be improved via the caging system and (2) clogging of the drainage system at the filter.

\section{Conflicts of Interest}

The authors declare that they have no conflicts of interest.

\section{Acknowledgments}

The authors wish to acknowledge the financial and physical support granted by the Ministry of Education Malaysia (ERGS/TK03(01)/1008/2013(05)) and Universiti Malaysia Sarawak. Also, special thanks are due to the technical staff of Geotechnical Engineering Laboratory, Faculty of Engineering, Universiti Malaysia Sarawak, for their assistance during the project.

\section{References}

[1] D. L. Royster, "Horizontal Drains and Horizontal Drilling: An Overview," Presented at the 59th Annual Meeting of the Transportation Research Borad, Washington, DC, USA, January, 1980.

[2] J. Ahmed, M. A. Ghazali, M. Mukhlisin, M. N. Alias, and M. R. Taha, "Effectiveness of horizontal drains in improving slope stability: a case study of landslide event in Putra Jaya Precinct 9, Malaysia," in Unsaturated Soils: Theory and Practice, Jatisankasa, Sawangsurinya, Saralump, and Mairaing, Eds., pp. 753-758, Kasetsart University, Bangkok, Thailand, 2011.

[3] W. Dharmawardene and N. Weimer, "A case history of the use of horizontal drains to stabilize a landslide in Alberta, Canada," in Proceedings of the 50th International Symposium on Landslides, pp. 893-896, A A Balkema, Rotterdam, Brookfield, 1988.

[4] D. Proudfoot, D. Law, and R. Tweedie, "Geotechnical solutions for roadway embankment and bridge abutment slope stabilization in northern Alberta," in Proceedings of the 51st Canadian Geotechnical Conference, pp. 393-401, Edmonton, Alberta, Canada, 1998.

[5] D. I. Cook, P. M. Santi, and J. D. Higgins, "Horizontal landslide drain length: state of the art and suggested improvements," Journal of Environment Engineering Geoscience, vol. 9, no. 4, pp. 241-250, 2008.

[6] K. C. Lau and T. C. Kenney, "Horizontal drains to stabilize clay slopes," Canadian Geotechnical Journal, vol. 21, no. 2, pp. 241-249, 1984.

[7] V. Gjetwaj, D. Znidarcic, A. S. Nossan, and N. Popovic, "Increase of slope stability with time by drilled drains," in Proceedings of 17th International Conference on Soil Mechanics and Geotechnical Engineering, Alexandria, Egypt, October 2009.

[8] R. P. Martin, K. L. Siu, and J. Premchitt, "Review of the performance of horizontal drains in Hong Kong," Special Project Report, SPR 11/94, 106, Civil Engineering Department, Geotechnical Engineering Office, Hong Kong, 1994.

[9] T. E. Stanton, "California experience in stabilizing earth slopes through the installation of horizontal drains by hydrauger method," in Proceedings of the 2nd International Conference on Soil Mechanics and Foundation Engineering, pp. 256-260, Rotterdam, Netherlands, June 1948. 
[10] D. J. Craig and I. Gray, Groundwater Lowering by Horizontal Drains, Geotechnical Engineering Office, GCO Publication 2/85, Hong Kong, 1985.

[11] I. Ishibashi and H. Hazarika, Soil Mechanics Fundamentals, CRC Press, Boca Raton, FL, USA, 2010.

[12] U.S. Army Corps of Engineers, "Investigation of filter requirements for under drains. Engineering waterways experiments," Standard Technical Memo. 183-1, 1941.

[13] Simona, "Simodrain drainage systems for rail traffic routes and road construction," 2012, http://cpp.com.sg/sites/default/files/ Simona\%20Drainage\%20System.pdf.

[14] H. Rahardjo, K. J. Hritzuk, E. C. Leong, and R. B. Rezaur, "Effectiveness of horizontal drains for slope stability," Engineering Geology, vol. 69, no. 3, pp. 295-308, 2003.

[15] T. Iserloh, J. B. Ries, J. Arnaez et al., "European small portable rainfall simulators: a comparison of rainfall characteristics," Catena, vol. 110, pp. 100-112, 2013. 


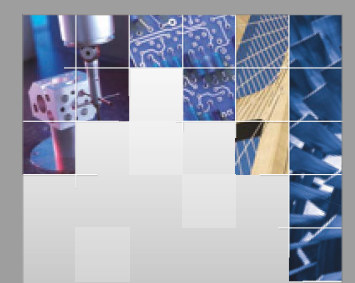

\section{Enfincering}
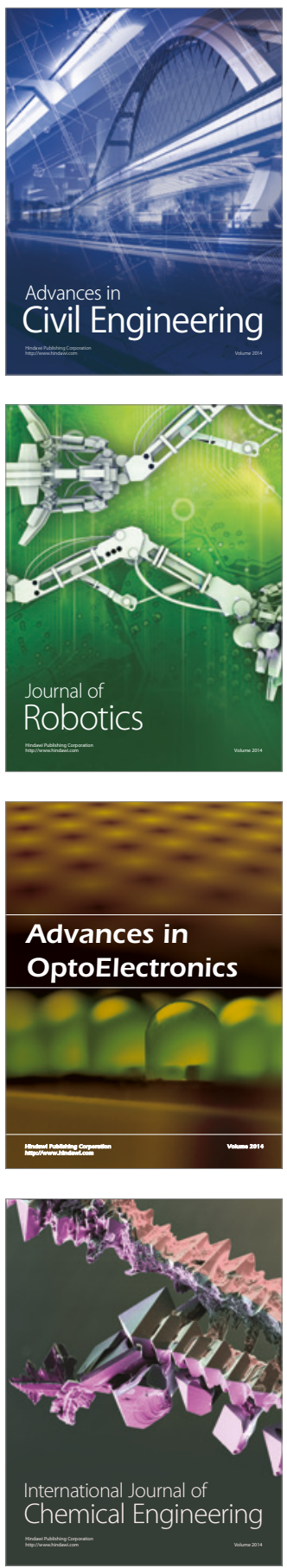

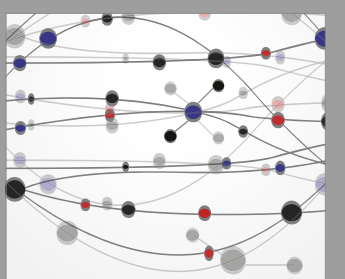

The Scientific World Journal

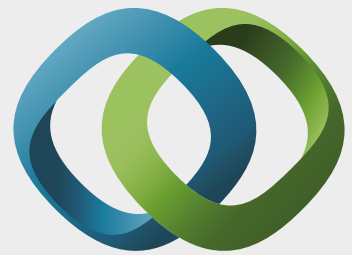

\section{Hindawi}

Submit your manuscripts at

https://www.hindawi.com
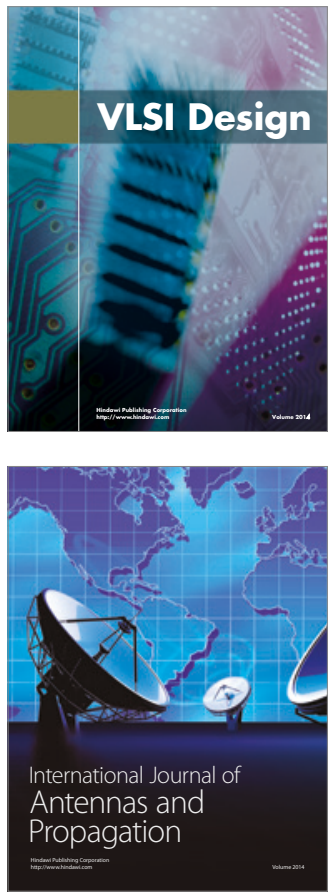

\section{Rotating}

Machinery
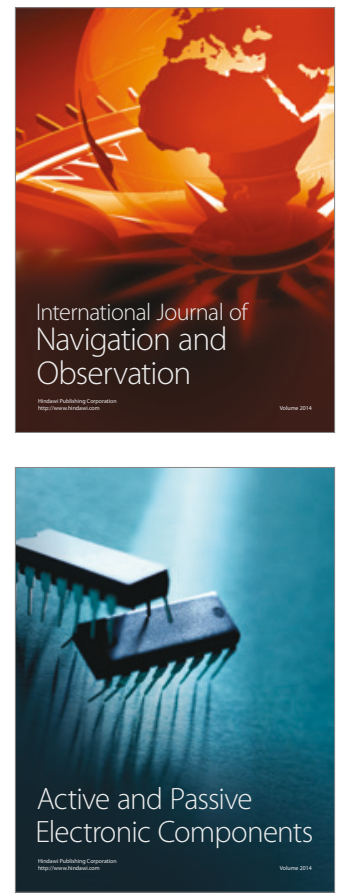
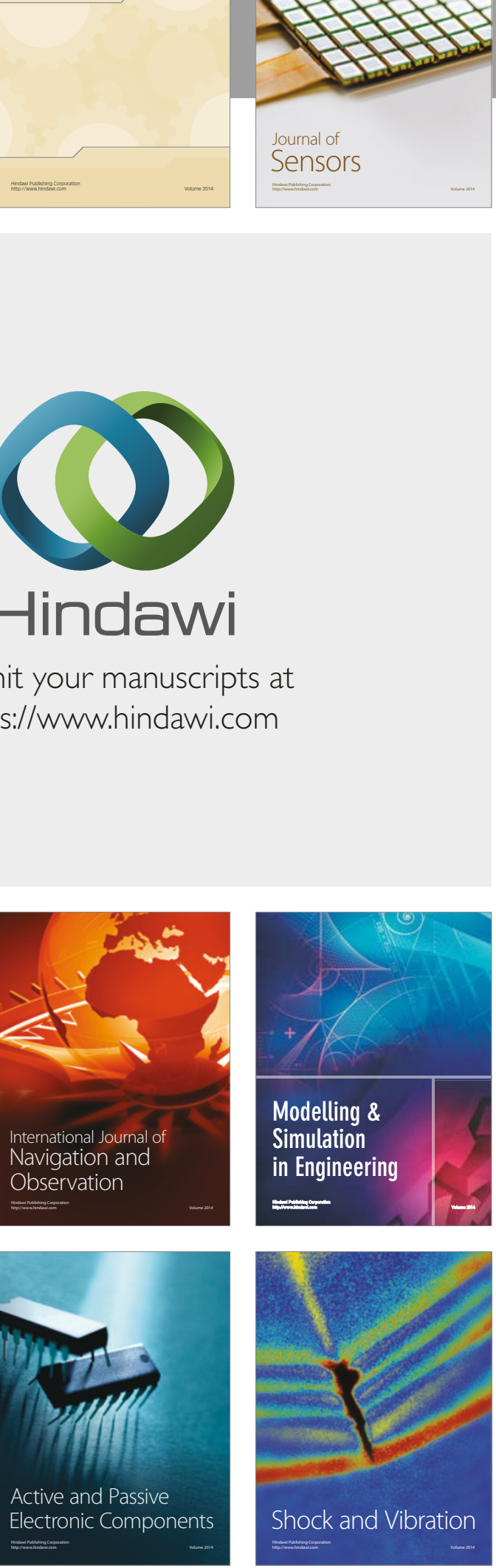
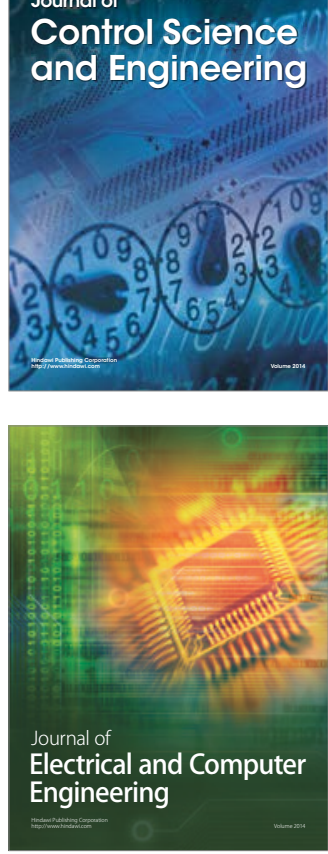

Distributed

Journal of

Control Science

and Engineering
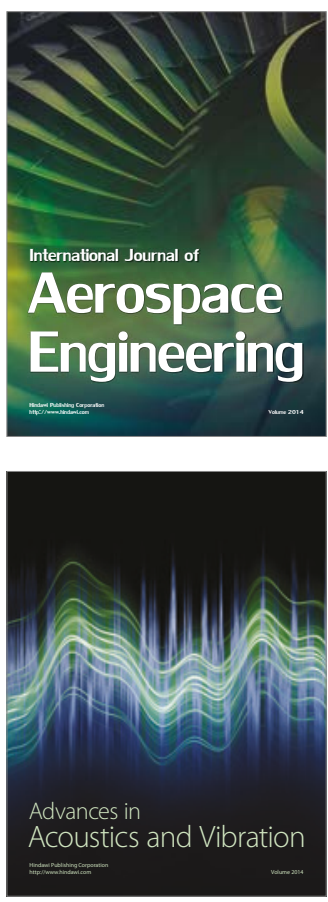

Sensor Networks 